\title{
Archetypal Motherhood and the National Agenda: The Case of the Indian Muslim Women
}

\author{
Ayshath Shamah Rahmath, ${ }^{+*}$ Raihanah Mohd Mydin, ${ }^{\ddagger}$ and Ruzy Suliza Hashim ${ }^{\hat{\imath}}$
}

\section{Abstract}

The grand narratives of Mother India posit women's emancipation as the central concern, insisting on her public participation in the educational and economic sectors. The relegation of the archetypal motherhood to the national periphery is strictly rooted in the Hindu traditional culture. The schisms of caste, class, and religion in contemporary society are normalised whilst the gendered undercurrents of domestic violence, chauvinism and religious sensibilities are ignored. Such polished idealisms are, in fact, far from the living reality of most women and girls across all spheres in the country. By reviewing notable texts from past and present, this research problematises the position of Muslim women in India, specifically during the nationalistic discourse and postindependent era. The national freedom struggle movement assured a democratic constitution, which primed Mother India as the figurative Indian woman encrypting ideologies from socioreligious discourses. The grand narratives often become instrumental in politicising the vested interest of the hegemonic class. The struggles of Muslim women were foregrounded not only in the gendered disparity of the religious domain but also in the socio-cultural disparities which excluded them from the domain of Indian womanhood. Mainstream history, literature and even women development organisations deliberately typified Muslim women along with the religious discourse. Briefly, in this paper, we infer that Muslim women were rendered invisible in the limelight of the archetypal Mother India, denying their social, political, cultural and literary participation. They were thus subjected to constitutional othering by the mainstream socio-political entities (who subjected them) at the onset of nationalism, which continues to exist in post-colonial discourses where women are expected to constantly negotiate their religious identity over their national identity.

Keywords: Mother India; Muslim Women; Nationalism; Constitutional Othering; National and Religious Identities

\footnotetext{
${ }^{\dagger}$ PhD Scholar,School of Language Studies and Linguistics, Universiti Kebangsaan Malaysia (National University of Malaysia)

${ }^{*}$ Corresponding Author, Email: shamah514@gmail.com

${ }^{*}$ Associate Proffessor of Literary studies, School of Language Studies and Linguistics, National University of Malaysia, UKM, Email:raihanah@ukm.edu.my

îProfessor of Literature, School of Language Studies and Linguistics at the Faculty of Social Sciences and Humanities, UKM, Email: ruzy@ukm.edu.my

(C) 2020 Rahmath et al. This is an Open Access article distributed under the terms of the Creative Commons Attribution License (http://creativecommons.org/licenses/by/2.0), which permits unrestricted use, distribution, and reproduction in any medium, provided the original work is properly cited.
} 


\section{Introduction}

It is timely to investigate the role and position of Indian Muslim women in the national context of Mother India, in a world where the perception of Islam and its pluralistic ideas are constantly debated. John L. Esposito and Ibrahim Kalin (2011) discuss extensively the role of mainstream media and literature in propagating misconceptions about Islam and how this accelerates the oriental construction of Muslims as the Other in the western context. In the context of Indian nationalism, which promised a democratic state system as a positive repertoire of modernisation, Muslims are relegated as the Other. Indian nationalism vested its democratic ideologies within the Hindu religious elitism. Commenting on the saffron wave in Indian nationalism and democracy, Hansen (1999) argues that the secular ideologies in India did not entail the removal of religion from the sociopolitical and cultural realms. Rather, it posited Muslims as "the symbol of national frustration and insecurity" (Devji 1992, 2). On a similar note, Veer $(1994,2)$ also argues that "from its very beginning in the nineteenth century nationalism in India has fed upon religious identifications", mostly on religious antagonism between Hindus and Muslims. Critically, the history of nationalism in India is also a history of differences and of exclusions.

India is a multi-lingual, multi-cultural society. Muslims in India belongs to diverse ethnic, cultural and linguistic domains according to the regional variance. Unfortunately, most of the studies on Muslims, specifically Muslim women in India, homogenises their identity as backward/Other (Sarkar 2001). As Amrita Chhachhi (1991) notes, in Indian context there is a tendency to see Muslim women as passive objects of oppression. Zoya Hasan (1998; 2014) also opines that Muslims in general and Muslim women in particular are treated as separate from the rest of the society, focusing only on religious identity. The reason behind such homogenisation is rooted in the age old religious antagonism perpetuated in the national discourse, which overarchingly emphasises Muslim identity along the communal lines.

Moreover, Mother India, the figurative construction of Indian womanhood rooted firmly in Hindu religious discourse, deliberately distanced women of minority communities including Muslims and Dalits from the national context (Sarkar 2001, 2008; Hasan 1998, Tharu and Niranjana 1994, Chakravarti 1989). Since my focus is particularly on the position of Muslim women in the national context of India, the question of women from other minority communities and cast are not addressed here. The concept of Mother India, arguably synonymous with ideal Indian women as well as the Muslim women cannot be homogenised. The departure from homogenisation itself shapes the need for thisstudy. Reviewing texts from past and present, in this paper, we substantiate that Muslim women were subjected to constitutional othering during the nationalist discourse and its reminiscence is passed on to subsequent decades, constantly deteriorating their identity as backward/oppressed Other in the national context

The image of Mother India personifies the archetypal concepts of motherhood immersed in the traditional values of chastity, humility and sacrifice. The hierarchical gender connotations were intuited as normal in the social psyche. Overlapping embodiments of caste, class and religion integrated within these gender dynamics were normalised at the onset of nationalism during the 19th Century, reincarnating the vulnerability of Indian women into a pious cult of spirituality constrained within the domestic and social sectors. This reembodied cult of Mother India was rooted in the traditional Hindu culture distinctly marking her public attire (dress), behaviour, habits and even religiosity, which was removed from the reality of women from other castes and religions. Namrata R. Mahanta and Banibrata Mahanta $(2015,48)$ illustrate this Mother/Goddess paradigm, a collective visualisation of the nation as Bharath Mata alias Mother India, as a political amplifier which consolidated the Brahmanical 
hegemony into an aggregated entity "to generate and synergize the entire country". This deliberate constitutional othering within the discourse of nationalism not only distanced women from other religions and castes but also normalised various schisms prevalent in the society then. In sum, the discourse of nationalism homogenised the heterogeneous female experience of Indian women under a single roof of Mother India, typically glorifying it as traditional and hence devine (Chakravarti 1989; Chatterjee 1989, 1993; Bagchi 2017; Bandyopadhyay 2018). Muslim women with their varied public attire, moral and religious chords were visibly demarked from this new idealisation of Mother India.

The grand narratives often become instrumental in politicising the vested interest of the hegemonic class. Sara M Corse (1997), in analysing the politics of nationalism and literature in Canada and the United States, reiterates that the grand narratives of national literature, both the literary and historical texts, are often viewed as cornerstones of the national culture, which is defined by a "collective consciousness" and marked by a distinctive set of values, tensions, myths and psychological foci, that in turn produce a specific identifiable national character. Briefing the debate on the origin of the discourse of nationalism between 16th to 19th Century Europe, Andrew Hadfield (1994) also argues that the literary canons and glorious histories of nationalism include some people and excludes some others. He observes that "some conceptions of national identity will clearly be more successful than others and become dominant; some will disappear..." (Hadfield 1994, 3). Even in the contemporary context, such texts are analysed and discussed in the academic and social sectors revealing the depth of the iconised national characters. In the context of India, Sikata Banerjee (2005) problematises the conceptualisation of motherland or nation as figurative Mother India, the spiritual cult of the mother goddess, encrypted from the Hindu traditional religion, as a symbol of masculine nationalism, which positions women in a divine or spiritual realm whose protection becomes the responsibility of the brave guards of the nation, the men. This resonates the politics of nationalists whereby the gender hierarchies of socio-political, economic and cultural realms were transmitted to the discourse of nationalism.

Thus, at the onset of Indian nationalism, Mother India became the personified national character which was impelled into the social psyche as the cultural symbol of India, and its protection became one of the prime concern of the nationalists. But this implication was vested on the majoritarian scale mainly rooted in the socioreligious discourse, distancing women from other minority classes and religions as the invisible other. Several scholars including Chatterjee (1989; 1996), Sinha (2000), Mondal (2002), Thapar (2006), Ramaswamy (2010), Banerjee (2005; 2012) and Bose (2017) have explicated these socio-political imprints behind the muscular nationalism, which was strictly encoded within the Hindu elitism, empirically distancing people from other castes, religions and classes. Thus, the socio-political and even the literary contributions of the rural, low caste and other religious groups, during and after independence, were erased from the grand narratives of nationalism (Chakravarti 1989; Sarkar 2001, Sinha 2000, Bose 2017). In the glory of national literature and an enlightened Mother India, Muslims especially women from Muslim communities were posited as the distant other. The following sections delineate the ideology and characteristics of Mother India and the politics of othering whereby Muslim women are either invisible or distorted in the national literary and historical accounts. Further, we inquest the visibility of Muslim women during and after Nationalism, a socio-political discourse that assured a democratic constitution, while the priming of Mother India encrypted ideologies from the socio-religious discourses.

\section{The Ideology of Mother India}

The grand narratives of national literature generously promoted the ideological resurrection of Mother India, attributing sacrifice and chastity as the essential qualities of the ideal Indian woman. The gendered undercurrents of domestic violence and 
chauvinism imbued within this spiritual cult of Mother India were never interrogated in the national context of 19th Century India. Jasodhara Bagchi (2017) in her book Interrogating Motherhood, traces the roots of Mother India to early 6th Century Sanskrit texts. She observes the revival of this image in the 19th Century nationalism, which helped to consolidate the orthodoxy of Hindu patriarchal word order. She observes:

The feminized Shakthi (power) that is iconized in this emblem of the motherland is an image drawn entirely on the pattern of a brahmanical family, where the entire resource and its control are in the hands of the male (Bagchi 2017, 51).

Since the glorification of Mother India was encrypted in the spiritual domain, the gendered undercurrents imbued within the figurative cult were normalised. Aparna Bandyopadhyay (2018) also reiterates that the Hindu revivalist nationalism posited the image of a chaste Hindu wife/mother at the heart of India. This personification, she says, is "harped on the conformity of women, precisely women of the upper caste, to normative codes of sexual and affective behaviour, particularly the ideals of satitva and patibratya that is, of the wife's chastity and fidelity, as the foundation of the spiritual supremacy of the Hindu nation" (Bandyopadhyay 2018). She affirms that the vast corpus of essays and manuals written during the period had substantiated the ideologies propagated by the Hindu revivalist nationalism encoded within the cultural codes of traditional Brahmanism. These works resonate the arguments postulated by Tanika Sarkar (2001) in her book Hindu Wife, Hindu Nation: Community, Religion and Cultural Nationalism, where she argues that what nationalism demanded from women was conjugality, where the household symbolized the embryonic nation and women symbolised the true patriotic subject.

Thus, the grand narratives of the period disseminated the pure/chaste and spiritual image of Mother India, that is, the loving heart of Hindu conjugality which was essentially heroic and patriotic and at the same time submissive to the male authoritative power politics. Bagchi $(2017,55)$ extensively discusses the role of nationalist literature in propagating these ideologies embellished within the spiritual cult of Mother India, "corresponding to the past, present and future of Indian history" which "collapses Muslim as well as British rule". Thus, Muslim women were out-casted from national literature and national history. Sugata Bose (2017) in his recent book The Nation as Mother and Other Visions of Nationhood decodes several essays that offer detailed historical and theoretical rephrase to official nationalism, anticolonial struggles and various ways in which the nation was engendered into Mother India. His essay 'Nation as Mother' from the book delineates glimpses from the literary and political history that engendered the nation into the constructive idealisation of an iconic Mother India. He explains some of the literary narratives of the 19th Century that became the political and religious triumphant in accelerating the Mother India motif during the political awakening of anti-colonial wars. Along the same line, Mrinalini Sinha (2000) also details the catalytic role of literary and political narratives in the discourse of nationalism. When Katherine Mayo, an American historian, attacked the Indian society and its culture in her highly controversial book on Indian women entitled Mother India (1927), a heated discussion opened up on the deteriorating position of Indian women against the backdrop of the nationalist iconography of Mother India.

The challenge for nationalist leaders was to empower Mother India, without encrypting the western orientation of modernity. The representatives from the women's movement in India reaffirmed the nationalist propaganda of Mother India, resisting the oriental degradation of Indian women's socio-political positioning and mediated specifically to build a new discourse of liberal Indian feminism. Mrinalini Sinha (2000) observes this new reorientation of Mother India as the signifier of essential Indian-ness which at the same time is different from the West and reaffirms the existing ideologies of traditional modernity. 
The contribution of organized women to the refashioning of Mother India thus went beyond the nationalist construct of the modern Indian women as the signifier of an essentialized Indianness for the assertion of cultural difference from the West. Rather, and more importantly, organized women's contribution to the nationalist project lay in making the discourse of liberal feminism available for the rearticulation of the modern Indian women as the agent of, and model for, an abstract nationalist Indian modernity (Sinha 2000, 626).

The construct of Mother India, as Sinha argues (2000), was both orthodox and modern at the same time. It highlighted Indian traditional culture as superior to the West, postulating Indian women as the agents of Indian modernity by safeguarding the image of Mother India. Elaborating on the ideological framework within which nationalism iconised Mother India, Chatterjee (1989, 625) argues that "the nationalist paradigm in fact supplied an ideological principle of selection. It was not a dismissal of modernity; the attempt was rather to make modernity consistent within the nationalist project". Thus the discourse of nationalism was assimilated in the Indian context, whereby the roots of traditional culture were reoriented into the realm of modernity.

At the core, nationalists were localising the Western ideas of modernity into the icon of Mother India, where the spiritual world supplanted the material world. Partha Chatterjee (1989) rightly observed, the dichotomy of the inner and outer worlds of women, which he articulates as the home/world dichotomy where the material essentialities of modernity endorsed the inner spiritual core of Mother India, was often controlled by men. Tanika Sarkar (2006) marks it as a political despotism where women's education became the basis for a companionate marriage, that is, to train them into becoming a family-oriented deity.
Though all these traditions seemed to privilege the woman's experience and emotions in multiple and prominent ways, they delineate, at the same time, a fundamentally problematic space for her by largely containing the liberation impulse and possibilities within devotional meditation and sexo-yogo. Ultimately, their combined effect was to heighten the sheer instrumentality of the woman's body and emotions within devotion itself (Sarkar 2006, 34).

These ideas reflect Chatterjee's (1989) arguments, where he marks the advent of modernity in the national context which essentially distinguished the social roles of men and women in terms of material and spiritual virtues. The degree of manners expected from women was high, but the degree of westernisation should be constrained within the spiritual and patriarchal domains.

Education then was meant to inculcate in women the virtues - the typically bourgeois virtues characteristic of the new social forms of "disciplining" - of orderliness, thrift, cleanliness, and a personal sense of responsibility, the patriarchal skills of literacy, accounting and hygiene and the ability to run the household according to the new physical and economic conditions set by the outside world (Chatterjee 1989, 629).

Thus, the social space for Indian women was extended to the educational and employment sectors to upgrade the material essentialities of modernity so as to achieve betterment for the household and the family. Both the mainstream nationalist and feminist writers of the time were following the same pattern. They embraced this extended social space for women into the coherence of the home/world dichotomy. But for women from other castes and religions, Mother India has become the symbol of religious bigotry.

First and foremost, the whole attire of Mother India was a refined version of the upper caste Hindu Brahmins, which was far from the reality of women from other castes and religions. 
Ayushman Mondal (2002) vividly explains that the spiritual embodiment of women's identity was transmuted into a cultural sign in the nationalist discourse, at first within the parameters of a 'Hindu' community and then within the wider scope of nationalism. Having been mapping different portrayals of Mother India since the 1880 s to the present, , Sumathi Ramaswamy (2010) also questions the integrity of sovereign national territory in projecting a Hindu goddess in its yearning form as Mother India, rejecting the cultural and religious plurality. Her study explores various ways in which the spiritual cult of Mother India becomes a focal point of debate between "authenticity and imitation, between tradition and modernity and religion and science, and between being essentially Hindu..." (Ramaswamy 2010, 2). For women from other religious and caste backgrounds, the discourse of nationalism thus became a political bias. They were visibly demarcated from the nationalist discourse. Secondly, to embrace the changing image of Mother India (Indian women), they had to find an agency within the inner dichotomy of home, which might constitute multiple communities based on different religions and castes. In the case of minority communities, it was not easy to embellish the spiritual doctrine of Mother India. Suchismita Chaudhury (2016) argues that Muslim women had been subjected to dual marginalisation as Muslims and as women. She observes the perpetual confusion among Muslims of colonial and post-colonial India to embrace the national equation of womanhood. Mahua Sarkar (2001) details the various tropes in the colonial and post-colonial India which villainised Muslim men and victimised Muslim women. Their contributions to the nation reformation process were never recorded in the mainstream historiography and literature. Chadhury (2016) marks the dilemma of Muslim women in such a context, where to embrace an agency prevalent in the mainstream sociocultural context becomes impossible. In the following section, we analyse the context and characterisation of the Mother India motif, where Muslim women were visibly demarcated as the subjugated other in the social context of pre- and post-colonialism in the 19th and 20th century.

\section{Characterisation of Mother India: Socio- Political Interventions}

The previous section had briefly analysed the ideological interventions of socio-political discourses in postulating the divine cult of Mother India as the touchstone of Indian women. This section examines the characterisation of the archetypal Mother India, which integrated the traditional spirituality into the realms of Western modernity. The 19th Century India bore witness to political disputes between colonisers and resisting nationalists where the power politics revolved around the tension between tradition and modernity, namely the interpretation of religion and the status of Indian women in society. The imperial rulers criticised the institutions of Sati, polygamy, female infanticide, purdah and child marriage as being oppressive to women and argued that Indians are chauvinist and hence backwards (Thapar, 2006, 82). Chatterjee (1989, 622) acknowledges these political disputes and argues that "by assuming a position of sympathy with the unfree and oppressed womanhood of India, the colonial mind was able to transform this figure of Indian women into a sign of the inherently oppressive and unfree nature of [the] entire culture of a country". To resist the British condemnation of Indians as being oppressive to women, the nationalist leaders became more consistent with the liberal Western ideas of education and employment for women. Rather than adapting to the material domain of Western civilisation, the Indian reformers remained faithful to the spiritual domain.

It followed that as long as India retains the spiritual distinctiveness of its culture, it can make all the compromises and adjustments necessary to adapt itself to the requirements of a modern material world without losing its true identity. This was the key that nationalism promoted for resolving the ticklish problems posed by social reform issues in the 19th Century (Chatterjee, 1989). Mondal (2002) also details the political transmutation of the spiritual Mother India into the national periphery, reorienting within the 
parameters of the Hindu community. Thus, the discourse of Indian nationalism had deconstructed the pious identity of Indian women constrained within the domestic circles and reinforced her identity into another realm of spirituality - 'the Mother India'. Suruchi Thapar (2006) analyses how the Indian nationalist movements modified the constraints of femininity and motherhood in accordance with the prevailing political ideology. Although it carved new paths for Indian women to step out from the domestic circles, the patriarchal realms were not entirely demolished. Motherhood, the striking aspect of femininity, was supplemented along with nationalist movements. In a similar line of argument, Ayushman Mondal (2002) also points out that Indian women were transfigured into a cultural sign rather than a material being with social and political needs during this juncture of national formation. Their freedom was extended from the inner clutches of domesticity to the much broader realm of the public sector, but their movements were still censored within the spiritual, social and cultural domains.

The spirituality was now fortified into the symbol of 'Mother India' that is, a reincarnation of the traditional divine cult of the goddess. Sure enough, nationalism adopted several elements from tradition as marks of its native cultural identity, but this was now a classicised tradition that is reformed, re-constructed, and fortified against charges of barbarism and irrationality. As mentioned previously, Partha Chatterjee (1989) argues that the hidden patriarchal norms under the material and the spiritual dichotomy of the nationalist movements which he connects to the concepts of home and world. The spiritual embodiment of Mother India thus fortified divinity, chastity and motherhood as the essential qualities of an ideal Indian woman. Tanika Sarkar (2001) brings the concept of conjugality into the discourse of nationalism. She affirms that "the Hindu nationalist strategy centered its critique of colonialism primarily on the loveless, purely deprivational, unrequited nature of its political arrangement, an arrangement which endowed the dominant group with absolute power and profile and subject people with helpless surrender - with no possibility of self-fulfilment" (Sarkar 2001, 39). Therefore, based on this premise, we assert that the nationalists, in such circumstances, became the revivalists who were revolutionising the position of women, only to posit them within the traditional schism of chastity and spirituality in hegemonic patriarchal clutches.

Critically, the characterisation of spiritual Mother India was immersed in religiosity, which distanced women from other castes and religions from the spiritual empowerment. Investigating the veiled layers of womanhood in India, Mondal (2002) also shares similar concerns by highlighting the overlapping embodiments of gender and caste in modern India. He argues that "[t]he history of embodiment overlaps with the convoluted and confused history of another sign denoting identity, namely jati", which he defines as a range of communities including different castes, regional people and religious communities (Mondal 2002, 918). The composite nationalism deliberately posited Hindu religious values as the principal orientation of Mother India, which is vehemently invested with Hindu symbolism and imagery, distancing the minorities. Uma Chakravarti $(1989 ; 1993 ; 2008)$ has contributed much to this discourse where she analyses the different layers of caste, religion and class integrated with the gender dynamics of Indian women. Chakravarti's (1993) article, "Conceptualising Brahmanical Patriarchy in Early India: Gender, Caste, Class and State", explores the powerful instruments of religious traditions which shaped the cult for women in India. Consequently, gender subordination in India is strongly connected to the caste discriminations.

The complex process of reinterpreting knowledge about the past became persuasive rhetoric in incarnating the Aryan (upper caste) image of women as the symbol of Indian women, which the Hindu liberals and conservatives upgraded alike (Chakravarti, 1989). Women from all other castes and religions disappeared during this course of nationalisation, "without leaving any trace of herself in the nineteenthcentury history" (Chakravarti 1989, 28). In her 
tripartite analysis, Chakravarti (1989) discloses the orientalists' effort in the romantic reconstruction of the Aryan past of women, followed by the cultural nationalists' effort in reconstructing a new identity for Indian women by highlighting Kshatriya/Aryan values, and the incongruity of such images of womanhood in contrast to the experience of women. Many women had internalised this notion of a Vedic Aryan woman with the essential characteristics of Mother India, especially the educated section of the society which promoted these ideas through literature and scholarly articles. Women's organisations constituted during the period such as Arya Nari Samaj by Keshu Chunder Sen in 1879 and Arya Mahila Samaj by Pandit Ramabai was notable in promoting such ideas. Issues like child marriages, female seclusion, enforced widowhood, and Kulin polygamy was brought under discussion in literature (Chakravarti, 1989). While Indian womanhood was refashioned during the nationalist discourse, it took new forms of embodiments with the changing socio-political discourses in the post-colonial period which was extensively reflected in mainstream media, politics and literature.

Mainstream literature thus became a tool to propagate the political views on womanhood. Surachi Thapar (2006) in her book, Women in the Indian National Movement: Unseen Faces and Unheard Voices, systematically analyses the active participation of women in the political upheavals during the process of Nationalism and the logic behind the historical veiling of their presence in public. Women's participation in the nationalist discourse was never glorified in the historical texts and pieces of literature. By analysing both popular literature and local publications including newspapers, vernacular magazines, autobiographies, biographies and oral-literary records of that period, Thapar states that:

At one level, they embodied specific national rhetoric on the construction of the 'new woman' and the conventions and traditions associated with that construct. Contributors in these magazines located femininity in the domestic and familial, femininity that would accommodate values of ancient Indian culture and the new western influences. A range of features was associated with the 'new woman'- she was educated, domesticated, nonviolent and non-antagonistic. On the other hand, they expressed concern over the emergence of a 'modern' woman who was unbridled, untamed and challenging (Thapar, 2006, 25).

The integration of modernity specifying the domesticity of Mother India was thus welcomed by both male and female writers, and they even criticised those who step out of these parameters. Education was highly recommended for women, but its intention was for the betterment of the family and society. It was essential for nationalist leaders "to project 'femininity' in ways which could enhance the 'masculine' or worldly virtues of Indian men, but at the same time also maintain traditional patriarchal relations with the family" (Thapar $2006,193)$. Thapar calls it as the politicisation of the domestic sphere, which continues to exist in the post-independent era.

In a nutshell, from the above discussion, it is clear that the femininity and sexuality of Indian women continued to be entangled in the cult of 'Mother India', during and after the nationalist discourse, highlighting motherhood, sacrifice and conjugality as the dominant characteristics of an ideal Indian woman. Since then, mainstream literature also followed the same path, promoting and questioning these distinct variables of femininity, culture and education to distil the multiple roles that the women play to endorse their Indian-ness. Femininity in this context imputes the feminine qualities ascribed to women, which idealise their manners, clothing, domesticity, religiosity and above all motherhood. Women who deviated from this divine symbolisation were postulated as the Other. Sikata Banerjee (2012) calls it muscular nationalism which interpellates the woman's body as a site of the political landscape. In her analysis of the social process involved in the 
nationalist discourse of different countries, Banerjee argues that there exist models of hegemonic masculinity embedded within the ideological symbol of womanhood which shapes ideas of citizenship in each country.

In the Indian context, the trope of Mother India demanded not only chastity and purity, but also religiosity to enthral citizenship. In brief, by merging the spiritual realm into the nationalistic discourse, the priming of Mother India distanced Muslim women from their national identity. Zoya Hasan (1998) surmises that women became a signifier of communal differences in India since it witnessed a resurgence of politicised religion. Mahua Sarkar (2001) criticises mainstream socio-literary historians for deliberately excluding the effort of Muslim women in social revaluation. She observes that "what looms large in both mainstream academics and popular discourse in contemporary India is their (Muslim women's) apparent difference (read: backwardness/conservatism) from the ideal modern (that is, Hindu middle class/upper caste) women" (Sarkar 2001, 220). She argues that the gendered and communal ideologies perpetuated by the mainstream literary, cultural and political historiographies denied Muslim women "even the circumscribed and sometimes dubious attention granted to Hindu/Brahmo women within a Hindu/Brahmo-dominated nationalist discourse, and to produce them either as invisible or as silent victims even when they wrote and spoke publically" (Sarkar 2008, 49). In a similar note, Esita Sur (2014) also argues that the dominant instrument of alienating Muslim women from the mainstream Indian society is through the construction of 'other'.

To resist such constitutional othering, Muslim reformist leaders were structuralising a counter identity for Muslim women. Mahmudul Hassan (2012) observes that Muslim reformist leaders during the colonial period espoused Muslim women's education and advancement, not as a part of the mainstream Hindu revivalism, but as a feminist subculture. At the same time, they were confused at the extent of freedom a Muslim woman can attain (Chadhury 2016). However, it is evident that Muslim women were extensively writing in magazines, periodicals, women's journals, autobiographies and much more (Rana 2017). These micronarratives have profoundly contributed to the heterogeneous identity of Muslim women in the colonial and post-colonial period. Sonia Nishat Amin has extensively written on the early struggles of Muslim women reformers and writers in establishing their norms in the colonial and postcolonial India. Amin's (1996) study focuses on the emergence of the Muslim "gentlewomen" as a counter-narrative to the mainstream idealisation of Mother India. She details the contributions of Rokeya Sakhawat Hossein, Shamsun Nahar, Nurjahan, Ayesha Ahmed and many others to the literary, educational and social sectors. The works of Muslim women authors in the 19th Century is very significant as they had highlighted the limitations of the mainstream social reform movements which distanced Muslim women from the figurative Mother India and also discussed the limitations of the social reform movements led by elite Muslim men. The exclusion of these Muslim women from the trope of Mother India is a perfect example of constitutional othering. In the following section, we discuss the multiple ways in which Muslim women are subjected to such constitutional othering within the nationalist discourse.

\section{Position of Muslim Women in the Context of Indian Nationalism}

This section problematises the position of Muslim women in the context of Indian nationalism, which assured constitutional equality for everyone but encrypted the majoritarian principles of religious despotism. In multicultural societies, where a plethora of languages and religions subsist, several questions thus arise: Whose interest is vested in a unilateral version of social reflection? What types of social facts are projected by the mainstream history and literature? The discussion above clearly depicts the hegemonies integrated by the mainstream history and literature in propagating the majoritarian social elitism. It also reveals the politics of Othering that underpins the nationalist discourse. The 
presumptions propagated by mainstream literature had either amplified or distorted particular images of a community, religion or nation in a broader sense. As Milton C Albrecht (1954, 425) points out, "[l]iterature is interpreted as reflecting norms and values, as revealing the ethos of culture, process of class struggle, and certain types of social 'facts'". He further analyses the reliability of reflection theories and their influences in literature, posing the question of invisible subaltern writings, signalling that the presumed social facts may not be in favour of subaltern or minority groups. Charles Taylor (1994) examines such politics of multiculturalism in his article, The Politics of Recognition, and argues that the distorted image of the subaltern/minority groups in the mainstream literary history often results in the misrecognition of their identity and culture. In the national context of multicultural India, Muslims are posited as the subaltern other.

The nationalist attempting to reclaim the traditional past to strengthen the vulnerable present ironically followed the same path of othering forged by the colonisers and distanced the lower castes and other regional and religious communities from the nationalist discourse. Om Prakash Dwivedi (2012) problematises the postulation of Muslims and other minority communities as the Other in the context of Hindu nationalism in pre- and post-colonial India. The roots of such discrimination against Muslims can be traced to the political upheavals of Hindu Mahasabha in the 1920s. He further condemns the derogatory religious politics of some national leaders who engendered violence against minorities in the name of nationalism. The efforts put forth by the rural, low caste and other religious groups in the construction of an Independent nation were erased from the grand narratives of national histories. Shibani Kinkar Chaube $(2017,271)$ points out that religion was one of the major controversial signifiers where the demand to turn India into a Hindu nation (rashtra) became a strong imprint which resonated the ideology that "Hindu is a geographical concept, Hindutva is a secular concept and Hinduism is a secular religion". He differentiates the struggles of communal movements and caste movements in his book The Idea of Nation and Its Future in India.

The religious minorities fight against discrimination and oppression, but they are proud of their religion. The depressed/backward castes have to fight not only discrimination/oppression; they have to fight for their dignity. The minority movements, as a result, almost always take political form, while the cast movements are always political and social (Chaube 2017, 272).

Thus, the minority struggles in the national discourse are more probable to be type casted within religious history. The worst aspect of such violence and degradation according to Dwivedi $(2012,5)$ "is the fact that it is always the victims from the minor communities who are projected as real monsters". Abdul Shaban (2018) also shares similar thoughts on the political exclusion and marginalisation of Muslims in India during and after the wake of nationalism. There were constant attempts by political groups, cultural organisations and mainstream media to demonise Muslims. The image of Muslims was constantly distorted in the grand narratives of nationalism. A. R. Kidwai (2007) observes that such negative representations of Muslims in national literature are derived from Oriental writings. Dwivedi (2012) also affirms that political activists and religious fundamentalists have furthered the task of British legacy in perverting the Muslim image. Consequently, when nationalism emerged as a religio-political discourse normalising the schisms of caste, class and religion, it encrypted the Western oriental ideologies of Othering. Gyanendra Pandey (2006) precisely points out the inbuilt routine violence embedded within the nationalist discourse which continuously constructs the social and political hierarchies where minorities are always hyphenated as subordinate or sometimes second-class citizens. The problems of the minorities are often concealed within the homogenised national history and culture.

In sum, the Hindu nationalistic discourse rendered Muslims to be in a minority position, minimising their contributions and efforts in 
nation formation. But what was the position of Muslim women in these literary histories? Were they silent throughout the pre- and post-colonial discourse? What are the contributions of Muslim women to the literary and cultural historiography of India? Sherin (2011, 14) discloses the considerable gaps in this area in Muslim narratives with the warning that locating "the literary expression of Muslim women in such contexts would certainly end up as a futile venture". The demand for recognition, as Taylor (1994) details, emerges within the subaltern or minority groups in establishing an identity that is socially accepted and valued. He further explains that "our identity is partly shaped by recognition or its absence, often by misrecognition by others, and so a person or group of people can suffer real damage, real distortion, if the people or society around them mirror back to them a confining or contemptible picture of themselves" (Taylor 1994, 25). In the context of Indian nationalism, Muslim women were posited as invisible in the socio-cultural, political, literary and religious realms. When the nationalist discourse postulated Mother India as the identifiable national character, Muslim women were visibly demarcated from this new reorientation of nationhood. The traditional Indian ideology of womanhood is bestowed in the archetypal figure of Mother India, distending its roots from Hindu religious principles. While the nationalist leaders postulated this personified image of a woman as the symbol of the Indian nation, mainstream literature propagated and fortified it. In this essay, we are trying to analyse the position of Muslim women in such a political context where their minority positioning distanced them from the national context, forcing them to mimic or retire from the general trends of macro narratives.

As we discussed earlier, it is obvious that Muslim women with their varied public attire, moral and religious chords were visibly demarcated from the new feminine equation of Mother India during the course of nationalism. Nida Kirmani (2013) observes that Muslim women were doubly disadvantaged in the country because of their religious and gender identities, particularly in the context of increasing communalism in the nationalist and post-colonial discourses. Apart from the gendered-religious identity, Muslims in India constitute other identities comprising their regional, local and social consistency, which are often overlooked in the national context and of which often positions Muslim women in the binaries of a backward/suppressed/oppressed class. In the colonial contexts, Indian men were positioned as the Other who oppresses women; in the context of Hindu nationalism, Muslim men were posited as the arrogant dictator who suppresses women.

Mainstream literature propagated these ideologies propounded by the hegemonic class and posited Muslim women as the backward Other in contrast to the perpetual exaltation of Mother India. Mahua Sarkar (2008) asserts that the representation of Muslim women as backward/suppressed victims was a stark contrast to the newly evolving and modern Indian women in the emblematic icon of Mother India, which was fervently rooted in Hinduism. She criticises both male and female writers of the 19th and 20th Centuries for "producing Muslim women as the backward other and hence in bolstering their own image as liberated and modern" (Sarkar 2008, 49). This invisibility and victim image of Muslim women in the written historiography of India was a constitutive element of nationalism. Similarly, Tahera Aftab (2008) in her incredible work Inscribing South Asian Muslim Women observes that as members of a religious minority in India, Muslim women stand at the periphery and hence hardly emerge as a significant factor in narratives. Although she addresses the oftrepeated myth of passive Muslim women being subjected to the dual tyranny of religious and patriarchal implications within a Hindu model of traditional womanhood, she provides various narratives as evidence that Muslim women were actively participating in both public and private affairs as full members of their communities. Sonia Nishat Amin's (1996) work also records the emergence of Muslim women in the field of education, literature and reform movements in the early 19th Century India. 
But in national literary works and historiography, such participation by Muslim women was often rendered invisible. As Mahua Sarkar points out, "it is hard to find attempts to systematically relate the 'exclusions/exploitation' experienced by one group of women to the selective 'inclusions/privileges' of another" (Sarkar 2008, 56). The struggles of these Muslim women were thus foregrounded not only in the gendered disparity of the religious domain but also in the socio-cultural disparities which excluded her from the domain of Indian womanhood. This is in line with the argument put forth by Partha Chatterjee (1989, 632), "Nationalist reforms do not, however, reach political fruition in the case of Muslims in independent India, because to the extent that the dominant cultural formation among them considers the community excluded from the state, a new colonial relation is brought into being". The problems of the minorities were deliberately excluded from the nation-state concerns, ideologically typifying the community alone to be responsible for their social degradation. But the issues faced by the women in Muslim communities were not foreign at the common ground. The quest for education, domesticity, child marriage and dowry was rooted in the mass culture of India, which was resurrected in Muslim communities as well. But Muslim women were always cornered along the religious line, overlooking the socio-cultural problems they face in the national context of India. Sadly, these grudges are carried forth to post-colonial India, where religious-political leaders magnify such differences in social, religious and cultural discourses to relegate the minority communities. Indeed, current scholars seem to affirm what Chatterjee $(1996,222)$ had contended in the '90s that is, "the root of our postcolonial misery [lies] not in our inability to think out new forms of the modern community, but in our surrender to the old forms of the modern state". In the final section of this essay we analyse the role of various women's movements in pre- and post-colonial India, which became instrumental in relegating the Indian-ness of Muslim women.

\section{Women's Movements in Post-colonial India: Deconstructing the Muslim-ness}

The previous section discussed how colonialism and nationalism mirrored similar hegemonic power politics of compliance, whereby women's role in the social construction was deconstructed by substantiating elite values of class, caste and culture. This new image of women created and promoted by the nationalist movement was later followed by various women's movements which continuously negotiated within the domestic and cultural norms. Apart from Chatterjee (1989), scholars like Surachi Thapar (2006), Ayushman Mondal (2002) and many others apprehend that the initial configuration of women's movements in India was entangled within the ideological apprehensions of Mother India prompted by the nationalist discourse, which were transformed and refashioned continuously within the premise of Mother India. Mondal (2002) assures that these ideological clutches were ushered in new forms of embodiment in the post-colonial context where the disparities of caste, class and religion expanded into the socio-political realms.

Indian women's movements, particularly in the post-independent era, should be evaluated as part of the multiplicity of class, caste, linguistic, religious, and ethnic propellants that make up the Indian constitution. Fainsod Katzenstein (1989) and Uma Chakravarti (2008) trace the initial waves of this deconstruction in the early onset of the women's movements in the preand post-colonial periods. Katzenstein (1989) presents her queries on the women development movements in India, which, according to her, by no means, constitute the issues of violence against women. She taxonomically compartmentalises these movements into six sectors that is, Partyconnected Women's Organisations, Autonomous Women's Group, Grass Root Organisations, Women's Research Institutes, Women's Development Organisations and the numerous 'old' and 'new' voluntary organisations. Some of the notable political organisations mentioned here include AIWC (All India Women's Conference) which is associated 
with the Congress Party, NFIW (The National Federation of Indian Women) and AIDWA (All India Democratic Women's Association Movement) which are both linked to the political CPM. She also details other macro and micro organisations centred on literary revivals like Manushi, Saheli, and Kali which promoted feminist literature analysing the issues of dowry, child marriage, domestic violence and the likes. But nowhere in these categorisations did she mention about the participation of Muslim women in such rival movements

The reasons behind the omission of Muslim women from the social scenario are closely connected to the constitutional othering which had been discussed in the earlier sections. Chakravarti (2008) shares her concerns regarding the exclusion of Muslims and Dalits in her scholarly articles. Her essay 'Beyond the Mantra of Empowerment: Time to Return to Poverty, Violence and Struggle' analyses various movements for women's autonomy and rights as well as the policies introduced by the State targeting the upgrade of women into the development process "while castigating them for remaining outside the process through their own inertia and backwardness" (Chakravarti $2008,10)$. Although her focus is limited to only three programmes associated with women's movements, the issues she interrogates in the article are applicable to most of the women's movements in India. The Women's Development Programme (WDP) in Rajasthan, the Total Literacy Campaign (TLC) in Andhra Pradesh, and the focus on Self Help Groups (SHG) in Gujarat and Andhra Pradesh had worked for the development and emancipation of women. The Target of WDP was to fight against patriarchy and 'claste' (caste and class) (Chakravarti 2008). TLC, the literary campaigns of the late ' $80 \mathrm{~s}$ and early '90s, precast education as an empowering tool to challenge both household and statebased patriarchies. Soon, the government took charge of these agencies and reinforced official stereotypes of women as being underprivileged, holding them responsible for their own conditions. And finally the third venture that is, SHG reinforced the State's systematic subversion of the struggles faced by the women's movements by reducing their development/empowerment to a limited financial venture in which structures of caste, class and patriarchy reproduced its essentials (Chakravarti, 2008). These three movements serve as a prototype of the revamps structured on women's movements throughout India since Independence, which excluded Muslims, Dalits and other minor sectors of the society (Chakravarti, 2008). This deliberate omission again signals towards the constitutional othering of Muslim women during the priming of Mother India, which carried the reminiscence of a glorious past rooted in socio-religious discourse, particularly elite Hinduism, which was passed on to the women developmental organisations in post-colonial India. Equally important is the structured disempowerment of Muslims, especially Muslim women, from the mainstream economy, politics and education sectors. Chaudhury (2016) argues that most Hindu male reformers, as well as women reformers, perceived Indian womanhood to be homogeneous. As we discussed earlier, in an attempt to revive Indian womanhood, they typified Muslim women as the "backward/victimised Other" (Sarkar 2001, 227). The idealised Indian (Hindu) women "saw herself as educated, outgoing and estimated her contribution to the nationalist struggle to be supreme. On the other hand, she sympathised with the Muslim woman for living out an uneventful life of anonymity shut out from the light of education, and political participation of any kind" (Chaudhury 2016, 478). These presumptions are the main reasons for the omission of Muslim women from the mainstream economic, political and educational revivals.

Radha Kumar (1997) in her book The History of Doing: An Illustrated Account of Movements for Women's Rights and Feminism in India 18001990, attempts at a comparative analysis of women's movements in India from the beginning of the 19th Century onwards. Briefing on the interpretative history of the past and present, she argues that the acceptance of 'women's representation' based solely based on gender equality results in monolithic 
interpretations of their identity which reiterate that bourgeois women cannot represent proletarian women, and upper-caste women cannot represent Dalit and other women (Kumar $1997,5)$. She vividly points out that women's movements in the national context clearly discriminate women on the basis of caste and religion, thus continuing past legacy. The agitations against dowry, rape, personal law and communal identity were brought under discussions at times, but the outstretch was limited to only certain groups. Since Muslim women were postulated as the Other in the extensive glorification of Mother India, their queries and problems were also revoked in the national context. These traits are still visible in contemporary women's movements, which highlight women as sexual objects, overlooking the distinct categories of class, caste and religion which constitute their heterogeneous identity. In analysing the constitutional discrimination against Muslim women in the post-colonial context, Vrinda Narain $(2008,6)$ argues that "the State's address to Muslim women constructs them as unequal, gendered citizens with a prior religio-cultural identity, which posited them as the other/subaltern". She assures that movements for women's rights in the postcolonial era were implicated and impacted by the imperial agenda as well as the nationalist project. The rights and problems of Muslim women were only framed along the religious lines in the larger domain of the democratic nation.

It was only in the late '80s that Muslim women's queries caught national attention with the Shah Bano case1, followed by heated discussions on Muslim Personal Law (MPL)2. Shah Bano's petition against her former husband to seek maintenance after divorce in 1985 was crucial,

\footnotetext{
${ }^{1}$ Read Dr. Vibhuti Patel's essay "The Shah Bano Controversy and the Challenges Faced by Women's Movement in India" (Problems of Muslim Women in India: 140-147). Also read Laura Dudley Jenkin's "Shah Bano: Muslim Women's Rights", Teaching Human Rights Online. University of Cincinnati.

https://homepages.uc.edu/thro/shahbano/allshahbano.h tm)

2 The Muslim Personal Law (Sharia) Application Act, 1937, sanctioned by government of India, allows parallel
}

as it commenced heated discussions on Muslim Personal Law. The Supreme Court's verdict highlighted the religious controversies rather than the judicial implications on the right for a divorced woman to seek maintenance. Various religio-political organisations and women wings throughout India reacted vigorously to the MPL. The All India Muslim Personal Law Board (AIMPLB)3, Bharatiya Muslim Mahila Andolan (BMMA), Awaaz-e-Niswaan (AeN), and the Muslim Women's Rights Network (MWRN) are some of the movements that gained national attention during and after the 1980s. But most of these organisation pressed on the religious identity of Muslim women, involuntarily fortifying that their problems are mostly related to religious principles. Esita Sur (2015) observes that in post-colonial India, narratives about Muslim women often revolve around tropes such as triple talaq, purdah, polygamy and Islam. There is a deliberate attempt to homogenise the problems of Muslim women only on the base of their religious identity. The Sachar Committee Report (2006) points the declining rates of Muslim women in education and employment sector. The report was an attempt from the government to evaluate the social, economic and educational status of the Muslim community in India. However, it reinforced the backward/passive image of Muslim women in the national context of India.

An effective approach for any Muslim women's movement should delineate the religious, social and economic positioning of women in the vast multitude of multi-lingual, multi-cultural and multi-religious autonomy of a secular nation. Unfortunately, most of the women's development movements framed Muslim women within the communal lines, either as passive victims of religious despotism or fervent

legislation for Muslims under Sharia Law (https://indiankanoon.org/doc/1325952/). Framing different civil codes for different religion is common in India.

${ }^{3}$ All India Muslim Personal Law Board (AIMPLB) was established in 1973, for the protection of Muslim Personal Law, at a time when Indian government was trying to subvert Sharia Laws over Uniform Civil Code. Visit the official website of AIMPLB for more details. http://www.aimplboard.in/ 
revivalists fighting against stringent religious rules. Zoya Hasan's argument seems right, "when it comes to Muslim women's rights there is an inordinate emphasis on personal laws as though they were entirely responsible for all their problems" (2014, 270). Suman Quazi (2016) in her article 'Muslim Women's Rights Movement in India' argues that women developmental organisations for Muslim women vehemently pressed for the fortification of minority identities which were deeply preoccupied with religion and religious institutions. As Nadja-Christina Schneider (2009) states, the existing women's movements in general as well as the emergence of new female subjectivities in India or elsewhere, seems to challenge and change secular-national gender discourse. Topics like talaq, polygamy, purdah and dowry were emerging as issues of concern for Muslim women all over India during the 1980s in the light of Shah Bano's case. Schneider (2009) observes this juncture as the turning point for the emancipatory Muslim women's movements to integrate the global image of Muslim women into the local context. Since this new image was already dominant in the global context, the collective national identity of Indian Muslim women was again challenged as the foreign other based on the religious discourse. In a recent work investigating the contextualisation of Indian Muslim women past and present, Ghazala Jamil (2018) contends that Muslim women are either victimised as members of a backward/oppressed community or posited as being communal until proven otherwise and its corollary Hindu as secular and tolerant by default.

These socio-political grudges are still evident in the national context of India. In 2017, the Supreme Court of India declared instant triple talaq null and void. Eventually, in 2019 the Indian government modified the Muslim Women (Protection of Rights on Marriage) Bill, whereby triple talaq is punishable under criminal offense4. Despite the mass protest from the Opposition and several Muslim organisations,

\footnotetext{
${ }^{4}$ The Muslim Women (Protection of Rights on Marriage) Act, 2019 is passed on $31^{\text {st }}$ July 2019. For more details
}

the government passed the revived Bill, which operates as an Act now. The All India Progressive Women's Association (AIPWAA) along with similar women's rights organisations criticised the political agenda behind such an Act., where the ban is only on triple talaq and it does not address the economic and social security of Muslim women afterwards (Kumar 2018). Flavia Agnes condemns the government's move pointing that the Supreme Court of India has already invalidated the instantaneous triple talaq, then why the government is criminalising it (Agnes as quoted in Saberin 2018). She also argues that the revived Bill does not elaborate rules on the maintenance of Muslim women after divorce. Siddharth Varadarajan (2018) elaborates these discussions on the issue of triple talaq and fosters the loopholes in the Bill, where a husband can still throw his wife out, without uttering talaq. In such case, "none of the protections envisaged for the abandoned spouse (by Shariah laws/Muslim Personal Law or legislative law) will be available for her" (Vardarajan 2018). He validates that most women in India, irrespective of religion faces a similar situation in marriage. Hence the amendments should be brought to Indian legal system by renaming it as the Indian Women (Protection of Rights on Marriage) Bill, which shall ensure protection for every Indian woman (Varadarajan 2018). He clearly depicts the biased political imprints within these claim of revivals in Muslim Personal Laws. Esita Sur (2018) extensively discuss the political context of the Bill and argues that there is a deliberate attempt to present Muslim women as victims. She affirms that the revised Bill "projects a lopsided view on gender justice, which remains political and does not consider the socio-economic wellbeing of these (Muslim) women. This Bill is a clear attempt to create a homogenised group of 'oppressor Muslim husbands' and 'helpless Muslim women victims'” (Sur 2018, 8). This, in turn, reinforces the victimised/oppressed/backward image of Muslim women in the Indian context. In sum, both the Muslim Personal Law and the Indian

refer, http://egazette.nic.in/WriteReadData/2019/209473.pdf 
Judicial system fails to provide justice for Indian Muslim women.

Not only political organisations and women's movement positions Muslim women in a marginal position, but also the nongovernmental organisations like NGO's positions Muslim women in dual margins. Srila Roy (2015) extensively discusses the transformations and new orientations of women's movements in contemporary India, where transnational wings of non-governmental organisations (NGOs) have professionalised feminist activism. She observes that unlike women activists of the 1970s and 1980s who worked for women's movements in an entirely voluntary manner, today's activists seem more attracted towards salaried roles in NGOs. This had successively created "a new class of paid 'full-time' activists", which in turn "contributed to the middle-class status of individuals while consolidating the elitism of the IWM (Indian Women's Movement)" (Roy 2015, 107). While in the past these movements masked the internal differences especially with caste, class and religion, now the hierarchies exist between higher officials, grass-root workers and targeted groups of women with an implied hegemonic elitism where Muslim women's queries are still dealt with discomfort. Farah Naqvi (2018) investigates the participation and acceptance of Muslim women in NGOs in her book 'Working with Muslims: Beyond Burqa and Triple Talaq'. She affirms that many established, mainstream NGOs work for the development of downtrodden classes including Muslims but "there was no single, trajectory that had led to the emergence of Muslim women in [NGO] leadership roles" (Naqvi, 2018). As Muslim women workers, Naqvi notes that they had embraced dual identities that is, as Muslims and as women. This posits them in dual margins whereby as Muslims they had to fight against communal stigmas, and 'as women and often as feminist, they had sought to redefine the meaning of Muslim-ness itself" (Naqvi, 2018). Explicating the troubled journey of some prominent Muslim women activists like Rehana Adeeb, Naqvi (2018) lashes at the dual crisis faced by Muslim women where they are either "too Muslim" or "not Muslim enough" for the mainstream socio-political or feminist discourses. B.S. Sherin (2011) shares similar concerns of the binaries that Muslim women are often caught in, that is, either progressive and anti-religious, or religious and hence oppressed. Sur's (2015) argument was right, the identity construction of Muslim women in the Indian context is a continuous production of discursive practices and tradition, whereby the significant factors like socio-economic marginalisation, national discriminations, the politics of the Indian State and also the Islamic traditional practices, perpetuates their subordination. Zoya Hasan's $(1998,87)$ argument is highly significant in this context, "[t]he dichotomies between public and private, nation and religious minority, uniform and personal laws, and group and individual have been major impediments in reconceptualising the relationship of the State to equal citizenship. The problem is how to arrive at [a]conception of citizenship based on the principles of democratic choice that guarantees equal rights without jeopardizing minority rights or undermining justice". Women's movements either feminist, political or communal, should break these shackles to explore the real problems of Muslim women in the social, political, cultural, economic and corporate sectors, giving them equal constitutional rights as members of a democratic country, not as members of a suppressed minority community. The emergence of Muslim women's movement has also arisen the need to understand their subjectivities and voices. As Hasan $(1998 ; 2014)$ points, it has definitely increased the selfconfidence of Muslim women along with an extended political conscience and also an urge to question the gender roles within the national and communal domains. Muslim women in the post-independent India are not a homogeneous category. Their subjugation, resistance as well as agency cannot be categorised as unitary. They are not passive victims; rather they have their ways and agency to negotiate with hegemonic patterns of constitutional othering and religious despotism. 


\section{Conclusion}

From the above discussion, it is clear that mainstream history, literature and even women development organisations deliberately framed the identity of Muslim women within the religious discourse. Muslim women were deliberately distanced from the nationalist discourse during the priming of Mother India, which was overwhelmingly encrypted in Hindu religious elitism. Reading different texts from past and present, this study highlights that nationalism homogenised different schisms of caste, class and religious disparities, the multitudes of disunities, within the title of a unified democratic Indian nation. The advent of modernity in the national context essentially upgraded the status of women to educational and employment sectors, but their contribution was always cornered within the margins of domesticity. To overcome this home/world dichotomy, Hindu nationalists vehemently posited Muslim women as the suppressed/backward other, supposedly invisible within the religious community and hence not expected to be upgraded to the resurrection of Indian womanhood. Given this line of argument, it is evident that Muslim women were subjected to Othering during the grand postulation of the figurative Mother India as the iconic national symbol. Post-colonial discourse carried these grudges from the past, whereby Muslim women have to prove their Indian-ness at different junctures of modernity, only by defending their religious identity. These ideologies are still entrenched in social, economic, political, cultural and various other discourses including women's movements and non-governmental organisations. The progressiveness of Muslim women is still measured in the national discourse within the binary angles of being either extremely religious or anti-religious. The contribution of Muslim women to the social, political, cultural, economic and corporate sectors should be delineated, giving significance to their constitutional rights as members of a democratic country, and not as members of a suppressed minority community.

\section{References}

Aftab, Tahera. (2008). Inscribing South Asian Women: An Annotated Bibliography and Research Guide. The Netherlands: Brill Publishers.

Albrecht, Milton. C. (1954). The Relationship of Literature and Society. American Journal of Sociology, 59 (5), 425-436.

Amin, S. N. (1996). The World of Muslim Women in Colonial Bengal, 1876-1939. E.J. BRILL: Leiden.

Bagchi, Jasodhara. (2017). Interrogating Motherhood. New Delhi: Sage Publication.

Bandyopadhyay, Aparna. (2018). Hindu Revivalism and 'Unchaste' Widows in Colonial Bengal. Gendered Asia: Special Issue of Asian Studies, XXXVI (1\&2).

Banerjee, Sikata. (2005). Make Me a Man! Masculinity, Hinduism, and Nationalism in India. NY: State University of New York Press.

Banerjee, Sikata. (2012). Muscular Nationalism: Gender, Violence and Empire in India and Ireland, 1914-2004. NY: New York University Press.

Bose, Sugata. (2017). The Nation as Mother and Other Visions of Nationhood. Haryana: Penguin Random House India Private Limited.

Chhachhi, Amrita. (1991). Forced Identities: the State, Communalism, Fundamentalism and Women in India. In D. Kadiyoti (Ed.), Women, Islam and the State (pp. 144-175). London: Macmillan Pvt Ltd.

Chakravarti, Uma. (1989). Whatever Happened to the Vedic Dasi? Orientalism, Nationalism and a Script for the Past. In Kumkum Sangari \& Sudesh Vaid (Eds.), Recasting Women: Essays in the Colonial History (pp. 27-87). New Brunswick: Rutgers University Press.

Chakravarti, Uma. (1993). Conceptualising Brahmanical Patriarchy in Early India: Gender, Caste, Class and State. Economic and Political Weekly, 28(14), 579-585.

Chakravarti, Uma. (2008). Beyond the Mantra of Empowerment: Time to Return to Poverty, 
Violence and Struggle. In Deepta Chopra \& Catherine Muller (Eds.), IDS Bulletin, 47 (1A), 10-17.

Chatterjee, Partha. (1989). Colonialism, Nationalism, and Colonised Women: The Contest in India. American Ethnologist, 16(4), 622-633.

Chatterjee, Partha. (1996). Whose Imagined Community? In Gopal Balakrishnan (Ed.), Mapping the Nation (pp. 214-225). London: Verso.

Chaube, Shibani Kinkar. (2017). The Idea of Nation and its Future in India. NY: Routledge.

Chaudhury, Suchismita. (2016). Accommodating the Muslim Women within the Social Psyche of a Colonial (Hindu) India. International Journal of English Language, Literature and Humanities, IV(VII), 474-481.

Corse, Sara. M. (1997). Nationalism and Literature: The Politics of Culture in Canada and the United States. UK: Cambridge University Press.

Devji, Faisal Fatehali. (1992).

Hindu/Muslim/Indian. Public Culture, 5(1), 1-18.

Dwivedi, Om Prakash (Ed.). (2012).

Introduction. The Other India: Narratives of

Terror, Communalism and Violence (pp. 1-13).

UK: Cambridge Scholars Publishing.

Esposito, John L., \& Kalin, Ibrahim (Eds.). (2011). Islamophobia: The Challenge of Pluralism in the 21st Century. NY: Oxford University Press.

Hadfield, Andrew. (1994). Literature, Politics and National Identity: Reformation to Renaissance. UK: Cambridge University Press.

Hasan, M. M. (2012). Marginalisation of Muslim writers in South Asian Literature: Rokeya Sakhawat Hossain's English Works. South Asia Research, 32(3), 179-197.

Hasan, Zoya. (1998). Gender Politics, Legal Reform, and the Muslim Community in India. In Patricia Jeffery \& Amrita Basu (Eds.), Appropriating Gender: Women's Activism and Politicized Religion in South Asia (pp. 71-88). NY: Routledge.
Hasan, Zoya. (2014). Religion, Feminist Politics and Muslim Women's Rights in India. In Kalpana Kannabiran (Ed.), Women and Law: Critical Feminist Perspectives (pp. 264-

273). New Delhi: Sage Publications India Pvt Ltd. Hansen, Thomas Blom. (1999). The Saffron Wave: Democracy and Hindu Nationalism in Modern India. New Jersey: Princeton University Press.

Jamil, Ghazala. (2018). Muslim Women Speak of Dreams and Shackles. New Delhi: Sage Publications.

Jenkins, Laura Dudley. (2000). Shah Bano: Muslim Women's Right. Teaching Human Rights Online. Retrieved from

https://homepages.uc.edu/thro/shahbano/inde x.htm

Katzenstein, Fainsod. (1989). Organizing Against Violence: Strategies of Indian Women's Movement. Pacific Affairs, 62 (1), 53-71.

Kidwai, A.R. (Ed.). (2007). Behind the Veil: Representation of Muslim Women in Indian

Writing in English 1950-2000. New Delhi: APH Publishing Corporation.

Kirmani, Nida. (2013). Questioning the Muslim Woman: Identity and Insecurity in an Urban Indian Locality. India: Routledge.

Kumar, Radha. (1997). The History of Doing: An Illustrated Account of Movements for Women's Rights and Feminism in India, 1800-1990 (2nd ed.). New Delhi: Zuban.

Kumar, Sanjay. (2018, 29th Dec). Controversial 'Triple Talaq' Bill Angers Muslims in India. Arabnews, available at http://www.arabnews.com/node/1427301/wor ld

Maya, Katherine. (1937). Mother India.

Retrieved from

http://gutenberg.net.au/ebooks03/0300811h.h tml

Mondal, A. (2002). The Emblematics of Gender and Sexuality in Indian Nationalist Discourse. Modern Asian Studies, 36 (4), 913-936. 
Retrieved from

http://www.jstor.org/stable/3876478

Mahanta, N.R \& Mahanta, B. (2015). The Nation as Goddess: Ritualizing Politics, Politicizing the Sacral. In R.N. Rai, M.S. Pandey \& Anita Singh (Eds.), Theory and Praxis: Indian and Western (pp. 42-52). UK: Cambridge Scholars Publishing. Narain, Vrinda. (2008). Reclaiming the Nation: Muslim Women and the Law in India. Toronto: University of Toronto Press.

Naqvi, Farah. (2018, 9th May). Why, How and When Do Indian NGOs Work with Muslims? One Answer: With Discomfort and Denial. Scroll.in. Retrieved from https://scroll.in/article/877692/why-how-andwhen-do-indian-ngos-work-with-muslims-oneanswer-with-discomfort-and-denial

Pandey, G. (2006). Routine Violence: Nations, Fragments, Histories. Stanford: Stanford University Press.

Patel, Vibhuti. (1995). The Shah Bano Controversy and the Challenges Faced by Women's

Movement in India. In Asghar Ali Engineer (Ed.) Problems of Muslim Women in India,

(pp 140-148). India: Orient Longman.

Quazi, Suman. (2016). Muslim Women's Rights Movement in India. CounterCurrents.org.

Retrieved from

https://www.countercurrents.org/quazi190416. htm

Ramaswamy, Sumathi. (2010). The Goddess and the Nation: Mapping Mother India. Durham:

Duke University Press.

Rana, Suman (2017). Recasting Muslim Women in Colonial Discourse: Rokaya's "Sultana's Dream". International Journal of English Language, Literature and Humanities, V(V), 394407.

Roy, Srila. (2015). The Indian Women's Movement: Within and Beyond NGOization. Journal of South Asian Development, 10 (1), 96117.
Saberin, Zeenat. (2018, 19th Sep). India: Triple Talaq or Instance Divorce now a Criminal Offense. Retrieved from https://www.aljazeera.com/news/2018/09/indi a-triple-talaq-instant-divorce-criminal-offence180919073349658.html

Sachar, R. K. (2006). Social, Economic and Educational Status of Muslim Community in India. New Delhi: Akalank Publications.

Sarkar, Mahua. (2001). Muslim Women and the Politics of (In)visibility in Late Colonial Bengal. Journal of Historical Society, 14 (2), 226-250.

Sarkar, Mahua. (2008). Visible Histories, Disappearing Women: Producing Muslim Womanhood in Late Colonial Bengal. Durham: Duke University Press.

Sarkar, Tanika. (2001). Hindu Wife, Hindu Nation: Community, Religion and Cultural Nationalism. London: Hustle \& Company. Sarkar, Tanika. (2006). A Book of Her Own, A Life of Her Own: The Autobiography of a

Nineteenth-Century Woman. In Dilip. M. Menon (Ed.). Readings in History: Cultural History of Modern India (pp. 32-64). New Delhi: Social Science Press.

Schneider, Nadja-Christina. (2009). Islamic Feminism and Muslim Women's Rights Activism in India: From Transnational Discourse to Local Movement - or Vice versa? Journal of International Women's Studies, 11(1), 56-71.

Shaban, Abdul (Ed.). (2018). Introduction. Muslims in India: Politics, Exclusion and Violence (2nd ed.). NY: Routledge.

Sherin, B.S. (2011). The Labyrinth of Dissonance: Islam and Women in Kerala (Doctoral

dissertation, Mahatma Gandhi University, Kerala, India).

Sinha, Mrinalini. (2000). Refashioning Mother India: Feminism and Nationalism in LateColonial India. Feminist Studies, 26 (3), 623-644.

Sur, Esita. (2015). Politics of Locating Muslim Women in Islamic Discursive Tradition in India. Space and Culture India, 3(1), 4-16. https://doi:10.20896/saci.v3i1.135 
Sur, Esita. (2018). Triple Talaq Bill in India: Muslim Women as Political Subjects or Victims? Space and Culture India, 5(3), 5-12.

https://doi.org/10.20896/saci.v5i3.299

Taylor, Charles. (1994). The Politics of Recognition. In Amy Guttmann (Ed.)

Multiculturalism: Examining the Politics of Recognition (pp. 25-74). Princeton: Princeton University Press.

Thapar- Bjorket, Surachi. (2006). Women in the Indian National Movement: Unseen Faces and Unheard Voices, 1930-42. New Delhi: Sage Publications.
Tharu, Susie \& Tejaswini Niranjana. (1994). Problems For a Contemporary Theory of Gender. Social Scientist, 22(3/4), 93-117. Varadarajan, Siddharth. (27 Dec 2018). Triple Talaq: Why Just Muslims, Let's Criminalise the Abandonment of All Wives. The Wire. Retrieved from https://thewire.in/law/triple-talaq-whyjust-muslims-lets-criminalise-theabandonment-of-all-wives

Veer, Peter Van der. (1994). Religious Nationalism: Hindus and Muslims in India. Berkeley: University of California Press 